\title{
RESCUE EXCAVATIONS OF THE DREN-DELYAN NECROPOLIS, SOUTH-WESTERN BULGARIA
}

\author{
Philip Mihaylov \\ Regional Historical Museum - Pernik, Bulgaria \\ e-mail: philip.mihaylov@gmail.com Original scientific paper \\ Received: 12. 5. 2020. UDC: 903:726.8"638"(497.2-14) \\ Accepted: 31. 7. 2020. 902.2(497.2-14)"2011/2018”
}

\begin{abstract}
In 2012, rescue excavations at the sites of "Bunishteto" and "Druganski Pat" uncovered and partially investigated a previously unknown necropolis, revealing a total of $400 \mathrm{~m}$ long stone piles with a total area of 6575 sq. m, 55 Early Iron Age graves and approximately the same number of graves from the $6^{\text {th }}-4^{\text {th }}$ century BC. By size and structure, the necropolis is unique: in a region without stone, substantial stone constructions had been erected, following a predesigned plan for a continuous usage of the terrain and the facilities. It was likely a regional necropolis.
\end{abstract}

Keywords: necropolis, Early Iron Age, Late Iron Age, gold pectorals, glass beads, urn, valley of the Struma, South-western Bulgaria

The necropolis is located between the villages of Dren and Delyan ${ }^{1}$, in today's South-western Bulgaria (Fig. 1.1), in the south-eastern periphery of the Radomir Plain, by Ushi Col, which links Konyavska to Verila Mountains (Fig. 1.1, detail). It is located at the foot of the eastern slope of Konyavska Mountains (Николов и Йорданова 2002, 115-116), at the altitude of $665 \mathrm{~m}$ a.s.1., on the left bank of the Matitsa River - a tributary of the Blato River, which drains the Radomir Plain before emptying into Struma River. Local climate has strong Mediterranean influences, consequence of unobstructed exposure to the Struma Valley (Николов и Йорданова 2002, 116).

\section{Archaeological and geophysical studies}

The Dren-Delyan necropolis was discovered in 2011, during rescue excavations prompted by the construction of the "Struma" motorway. The area designated for the motorway was excavated in full in 2012 (Михайлов 2014, 6076). The excavations benefited greatly from the geophysical surveys conducted

\footnotetext{
${ }^{1}$ Dren is part of the Municipality of Radomir, District of Pernik; Delyan - Municipality of Dupnitsa, District of Kyustendil. 


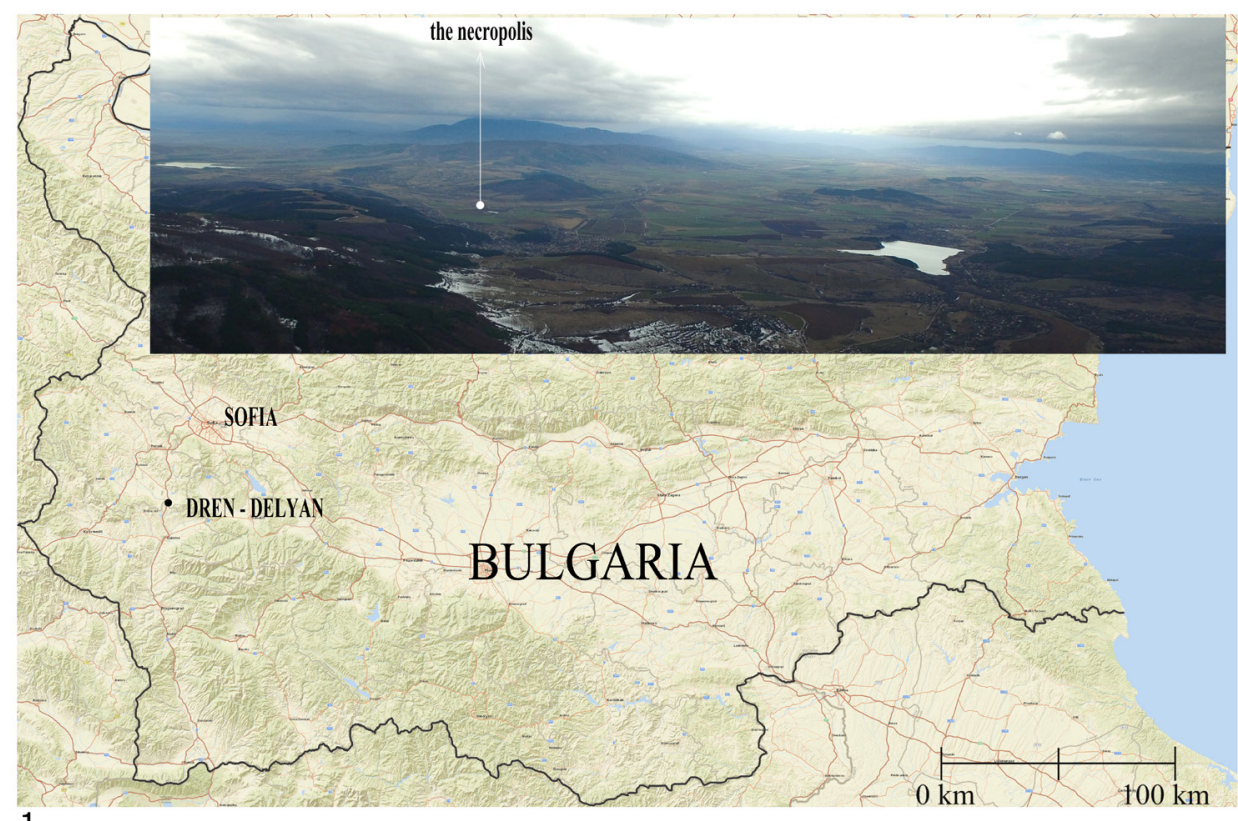

1

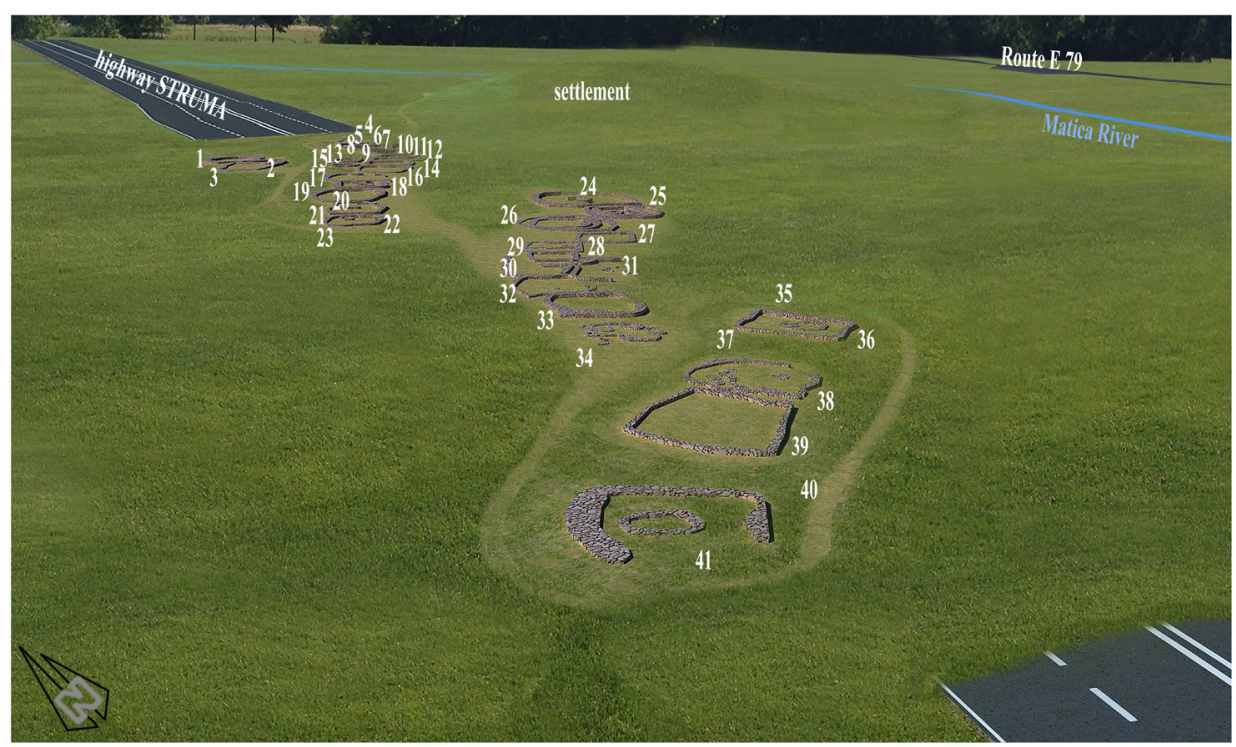

2

Fig. 1. 1. Map of Bulgaria with the Dren-Delyan necropolis;

2. 3D reconstruction of the Dren-Delyan necropolis

Сл. 1. 1. Мапа Бугарске са некрополом Дрен-Дељан;

2. 3D реконструкција некрополе Дрен-Дељан 
in 2011 (Зидаров, Бакъмска 2012, 186-188). In 2014-2015, renewed excavations opened the area to the west from the motorway (Михайлов, Гюрова 2015, 153-157; Михайлов 2016, 284-286), following reports of partially destroyed and scattered archaeological structures, but revealed no new parts of the huge necropolis.

Inspired by the results of the 2011 excavation season, in 2015-2018 the team undertook large-scale geophysical surveys (Fig. 2.1), with a range of methods, including an experimental overlap of different methods on certain sectors (Михайлов, Цанков 2016). All principle geophysical methods were used: geo-radar, geo-magnetics and electrical resistivity. These were supplemented by kappametry (for correlation of magnetometry data to rock, sourced from the excavated burial structures) and aerophotogrammetry (Михайлов, Цанков 2018).

We had hoped that these non-destructive methods would assist in plotting the planimetry and topography of the construction sectors of the Dren-Delyan necropolis, spared by the motorway. Unfortunately, that was not the case. During the 2018 excavation season, efforts focused on the most prominent geophysical anomalies refuted the anthropogenic origin of the said anomalies. On the contrary - these were proved, beyond any doubt, to be of geological origin. The regular outlines and the apparent agreement with the plan of the necropolis turned out to be a mere quirk of chance (Михайлов 2019). On top of that, a Roman Age building, not registered as a geophysical anomaly, was identified through the application of purely archaeological methods (Михайлов 2019). The area had been surveyed by both geo-radar and magnetometer, and while the former method had indeed registered one anomaly in the vicinity, it had completely missed the building itself.

Thus, for this site, as on several other sites, the best results were delivered by the electro-resistivity method (Михайлов, Цанков 2018). Data from the geo-radar survey proved to be, regrettably, entirely misleading.

\section{Description of the necropolis}

On the slope, immediately underlying the turf, concentrations of carefully fitted small-size crushed rocks and flagstones were detected, arranged in three parallel rows along a north-eastern/south-western axis (Fig. 1: 2; 2. 2). The number of excavated structures, to date, is 40 , with combined length of 400 meters (Fig. 1:2) and total surface area of over $6575 \mathrm{~m}^{2}$. As excavations on Structure 40 identified no traces of ancient human activities (Fig. 1: 2), Structure 40 is not counted against the total number of structures.

Presently, two phases are distinguished at the necropolis: early phase from the second half of the $9^{\text {th }}$ up to the $8^{\text {th }}$ century BC (first phase of the Early Iron 

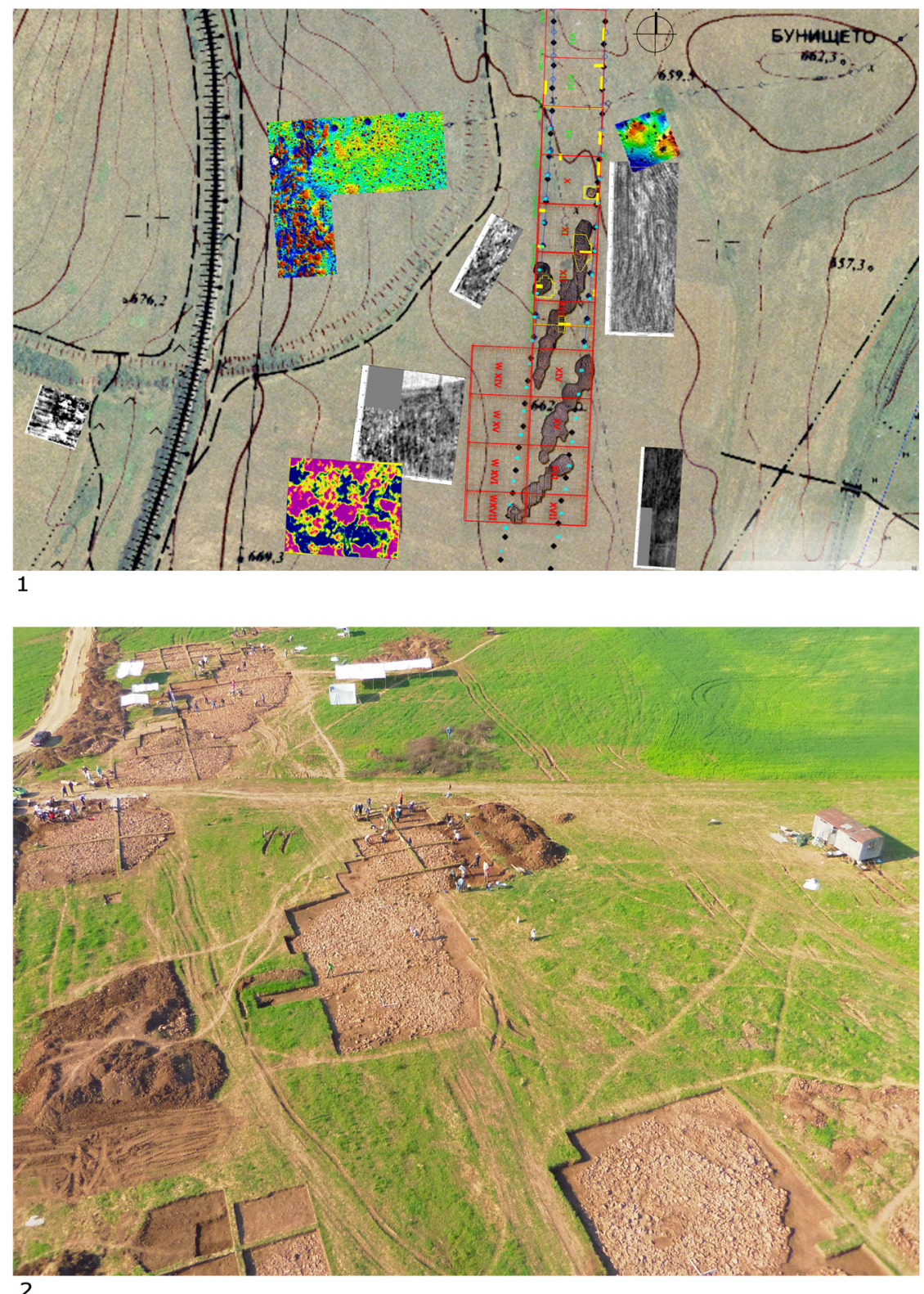

Fig. 2. 1. Orthophoto, with superimposed topographic map, square grid with the necropolis and geophysical surveys;

2. Aerial photo of the necropolis - with the stone structures

Сл. 2. 1. Ортофотографија, са преклопљеном топографском мапом, квадратном мрежом са некрополом и геофизичким рекогносцирањима;

2. Фотографија некрополе из ваздуха - са каменим структурама 
Age), and later phase - from the second half of the $6^{\text {th }}$ century up to the first half of the $4^{\text {th }}$ century BC. Chronologically, the necropolis evolved along the south-north axis.

In the south, stone covers are noticeably less carefully constructed. The rocks had not been fitted carefully; some pieces are larger and very roughly shaped, making the earlier graves and structures more susceptible to disturbances by modern ploughs. Deterioration had been further facilitated by the practice of utilizing large unshapen stones as markers for some of the Early Iron Age structures (Fig. 3: 1). In contrast, the stone covers in the north had been very carefully built from uniform, well-fitted stones, and there are almost no disturbances.

\section{The first phase - cremations}

The earliest graves stand out typologically and topographically. These were found in the southern sector, and consist of urns with cremated bones, placed in shallow pits dug into the ancient surface. Despite the lack of evidence for urn covers, it is only logical to assume that such existed. The fact that none of the 55 urns overlaps with or disturbs another, led the team to assume the presence of place-markers. Likely markers, surviving to this day, are the large amorphous stones. Perhaps the urns were buried shoulder-high and covered by soil, or, less often, by several stones. At the time of discovery, the sole indicator of a pit was the considerably lower density of the deposit.

According to the degree of preservation of the surviving structures, these could be assigned to three groups.

The urns of the so-called Structure 37 frame a large rectangular space. The vessels mark its periphery, while the central area contains no archaeological finds. Large and medium-sized unshapen stones line the northern and southern sides. This is the best preserved EIA structure.

Two mound-like structures (nos. 24 and 26) present a different situation. These had been used over an extended period, producing the perceived moundlike shape (there are no actual traces of embankment). In both instances, the LIA stone structures, typical for the necropolis, had been arranged around primary EIA stage I graves (Fig. 3: 2).

Structure 38 offers yet another variation. Its LIA graves and the associated ritual activities disturb, and occasionally destroy, about 35 graves from the early phase of use of that necropolis (Fig. 3: 3).

The earliest stone structure is Structure 41 (Fig. 3: 4). It is rectangular, with three walls and a single stone feature, without a stone embankment. There are several graves at the centre, dated by the associated pottery finds to the EIA. According to its construction and typology, this feature is an intermediary between the EIA 


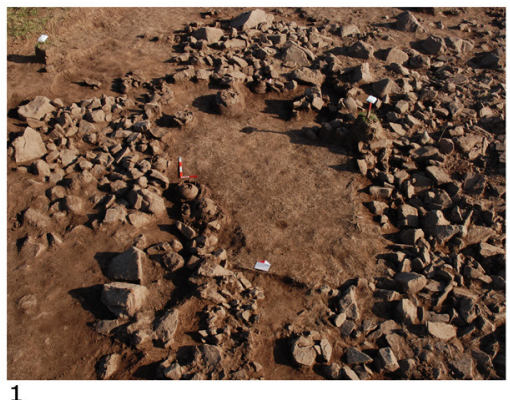

5
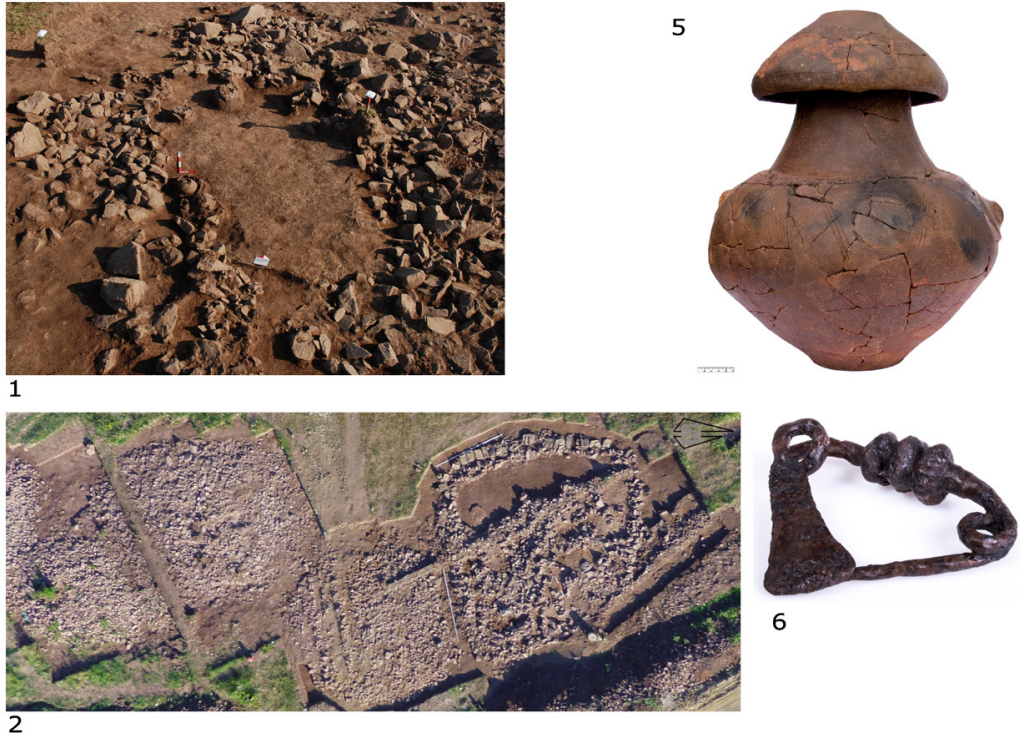

6

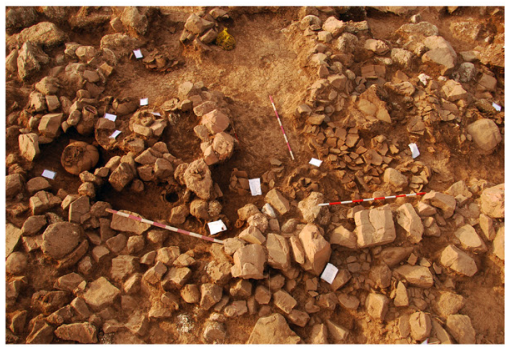

3

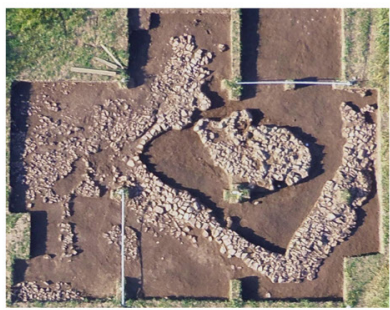

4
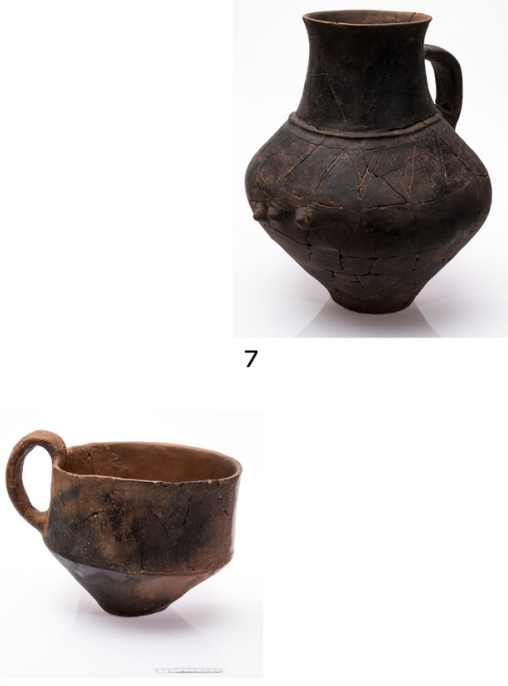

7

8

Fig. 3. 1. Structure 37 from the Early Iron Age; 2. Stone structures from the Early Iron Age and the Late Iron Age; 3. Early Iron Age structures destroyed by the Late Iron Age structures; 4. The earliest stone structure; 5. Urn from Structure 37; 6. Fibula from Structure 37; 7. Urn from Structure 39; 8. Grave gift from Structure 39

Сл. 3. 1. Структура 37 из старијег гвозденог доба; 2. Камене структуре из старијег и млађег гвозденог доба; 3. Структуре из старијег гвозденог доба које су структуре из млађег гвозденог доба уништиле; 4. Најстарије камене структуре; 5. Урна из Структуре $37 ;$ 6. Фибула из Структуре 37 ; 7. Фибула из Структуре $39 ; 8$. Гробни прилог из Структуре 39 
stage I urn burials and the stone burial heaps of the second half of the $6^{\text {th }}-$ first half of the $4^{\text {th }}$ century BC. It is impossible to establish whether all individuals buried in that feature were placed in urns. Modern agricultural activities had disturbed and mixed up the cremated remains, the pottery sherds, and the small hewn stones.

Funeral pyres had been arranged outside the burial structures. In all EIA graves, the cremated bones, along with the burial gifts, had been placed in urns; the grave goods had also been presented at the pyre. The condition of the metal artefacts and the bones suggests that they had been exposed to very high temperatures - above $1000^{\circ} \mathrm{C}$, as one urn contained iron slag. The condition of the skeletal material confirmed the conclusion that the process of incineration had been very thorough. Over $95 \%$ of burned bones had been heated to the point of calcination, or near calcination. This means that the colour of the bone surface, as well as the fractures, had turned uniform white (N9.5, N9), result primarily of combustion of the bone collagen. Surface colours associated with incomplete combustion (i.e., brown, black, grey, and blue) had not been observed. This uniform colouring of bone surfaces can be taken as evidence of intense incineration of the deceased, carried out on a strong fire, above $1000^{\circ} \mathrm{C}$, with unobstructed influx of oxygen (open fire). The singular dental roots discovered among the bone material corroborate this conclusion, as the dental crown fragments into microscopic particles at temperatures above $800^{\circ} \mathrm{C}$ (Correia 1997).

No $7^{\text {th }}$ century BC material has been found on the site to this date. Nevertheless, extrapolating from the overall topographical continuity - especially that between Structures 24 and 26, as well as in light of the "architectural template" exemplified by Structure 41 and elaborated in the $6^{\text {th }}-4^{\text {th }}$ century BC, the necropolis was likely utilized continuously from the start of the Early Iron Age until at least the $4^{\text {th }}$ century $\mathrm{BC}$, and the graves from the hiatus period are likely located outside the excavated area. On the other hand, there are no known sites from the second half of the $8^{\text {th }}$ - first half of the $7^{\text {th }}$ century BC in the area, and thus the chronological gap registered at the necropolis could actually signal a hiatus in its use during this period. Only future research could tip the scales in favour of either hypothesis.

\section{The second phase - cremation and inhumation}

During the second phase, most graves and ritual structures within the necropolis had been constructed of stone. This fact cannot be stressed enough, as the area is entirely lacking in this material. The "bedrock" is reddish clay, with very few inclusions of minute silicate pebbles (Бакъмска/ Михайлов 2012, 189, Обр. 1). All raw materials - mostly red sandstone - for the $6^{\text {th }}-4^{\text {th }}$ century BC structures had to be transported from elsewhere. An outcrop of this terrigenous 

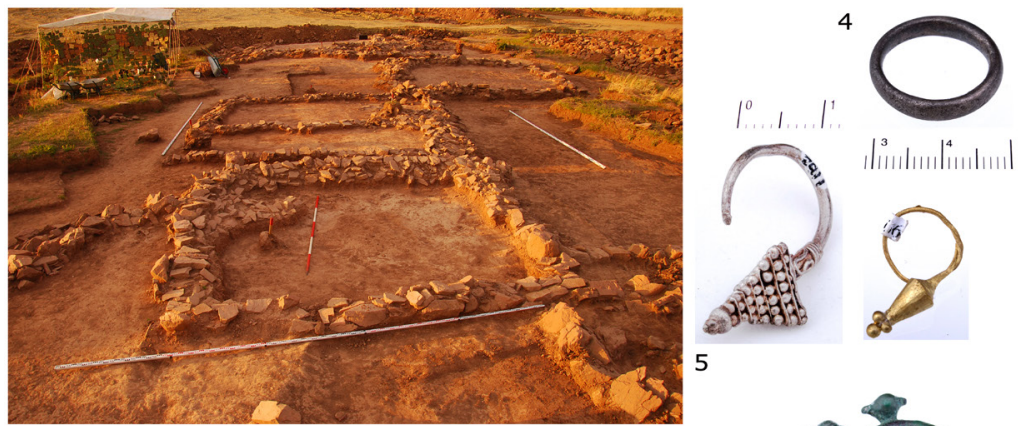

1

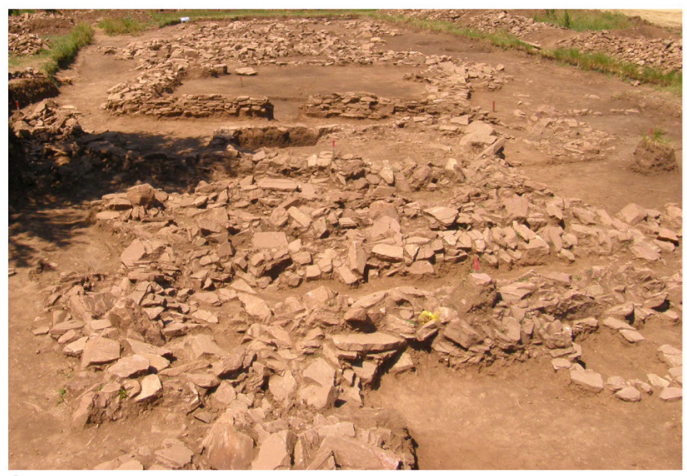

2
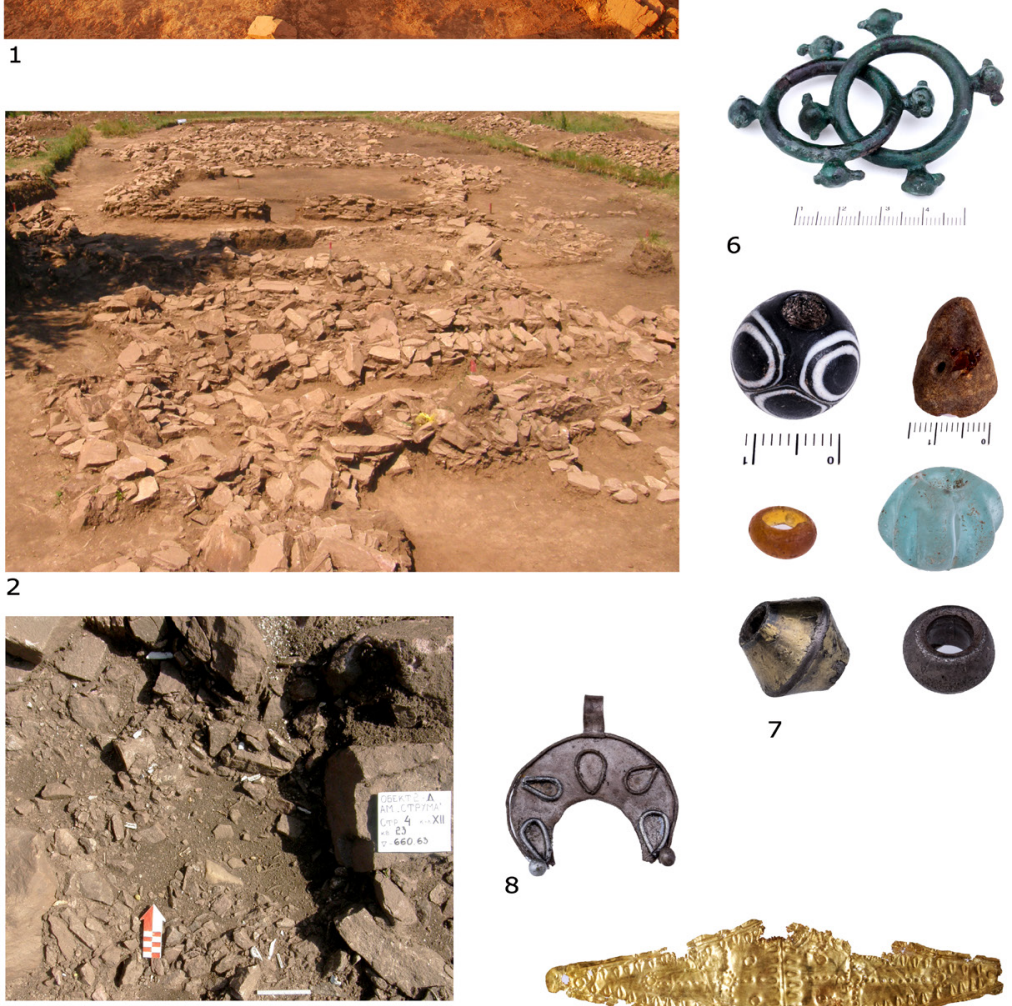

6
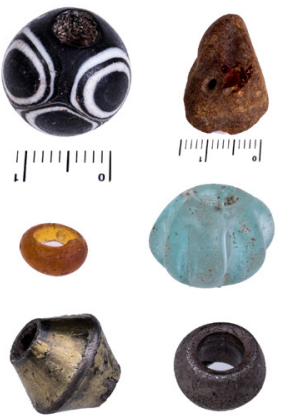

7

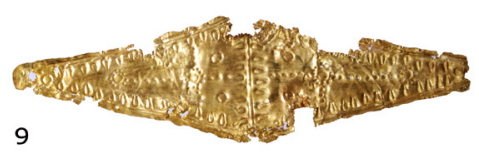

Fig. 4. 1. Central structures - constructed of just one to two courses of flagstones; 2. Massive stone structures; 3 . Human remains scattered between the stones; 4. Silver circlet; 5. Silver and gold earrings; 6. Bronze circlets; 7. Silver, bronze, amber, and glass beads; 8. Silver lunulae; 9. Gold pectoral

Сл. 4. 1. Централне структуре - саграђене од само једног или два низа камених плоча; 2. Масивне камене структуре; 3. Људски посмртни остаци раштркани међу камењем; 4. Сребрна трака; 5. Сребрне и златне наушнице;

6. Бронзане траке; 7. Сребрне, бронзане, ћилибарске и стаклене перле;

8. Сребрне лунуле; 9. Златни пекторал 
rock is found $800 \mathrm{~m}$ to the west (Fig. 5: 2), near the summit of an elevation, the foot of which is occupied by the necropolis, where extraction trenches can still be discerned today (Fig. 5: 1).

The fact that the commemorative and burial stone structures lie directly under the modern surface means that they used to be exposed in the past, buried only later by the erosion of the deforested steep slope above it. This is also suggested by the complex organization carried out over a long period of growth, and the lack of disturbances in the old structures.

Several types of burial and commemorative structures can be distinguished in the second phase of the necropolis, but an explanation for this differentiation is deemed premature at this stage.

Some of the grave covers (nos. 24 and 26) resemble low tumuli. These had been built and used over long periods and produce artefacts spanning from the Early to the Late Iron Age. They have a near-circular shape, thirteen meters across and the maximum height of $0.50 \mathrm{~m}$.

The most typical stone cover during the second phase of the necropolis, found on top of commemorative structures and graves alike (Structures 1-2, 11$16,17-18,19-22,34,36,38)$, is almost flat, conforming to the natural inclination of the slope. More often than not the central structures had been constructed from just one to two courses of flagstones (Fig. 4: 1). The corners of most structures had been reinforced in a fashion, with small and medium-size crushed stone pieces - an indication of prolonged use. Another pointer to this is the accumulation of a deposit, associated with repeated exploitation of the rectangular structures. This $0.05-0.15 \mathrm{~m}$ thick layer is only registered in association with larger structures.

The third type, illustrated by structures nos. 5-10 and nos. 28-33, consists of stone covers almost indistinguishable from the ground, resembling stretched north-east/south-west low banks (Fig. 4: 2). When the protective stone cover was lifted, a group of rectangular structures came to light, about ten by six-seven meters large. This third type is similar to the second one, but constructions used four to five courses of stones.

Considerably smaller, irregularly shaped structures were found attached to the large rectangular stone covers. The graves and the bulk of finds are associated precisely with those smaller features, constructed preferentially on the southern and western, rarely the eastern, peripheries of the large stone coverings.

The practice attested at the necropolis is cremation, ${ }^{2}$ performed away from the burial structures. In some instances, the cremated bones and burial gifts

\footnotetext{
${ }^{2}$ The type of wood registered most often is oak. In some structures, fragments of beech/plane tree and plum tree were found. From the EIA, all identified wood material is fir (Михайлов 2014, 65, footnote 5).
} 


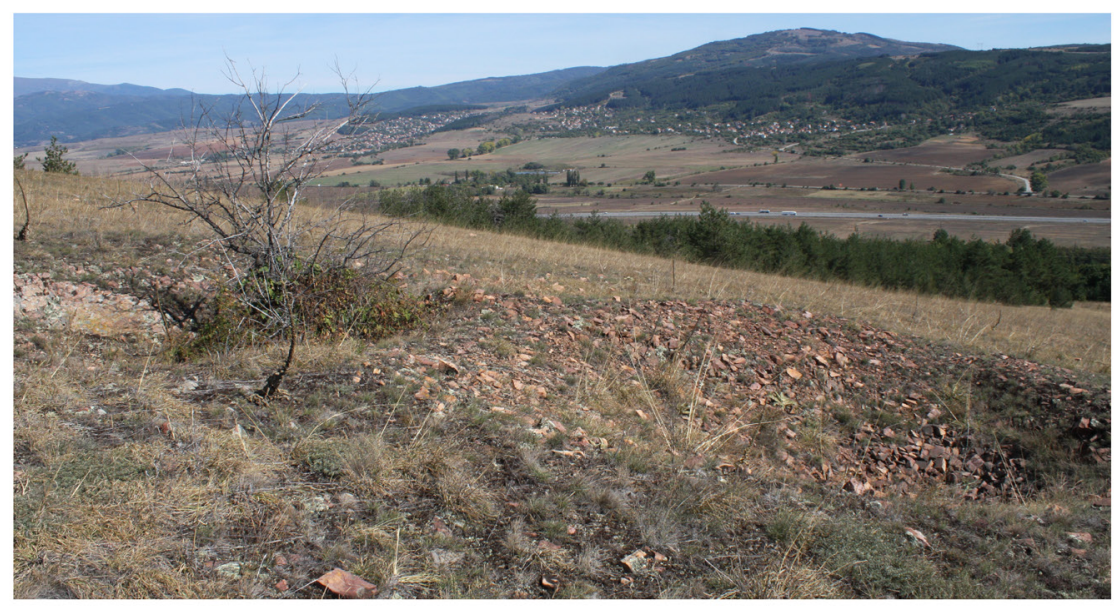

1

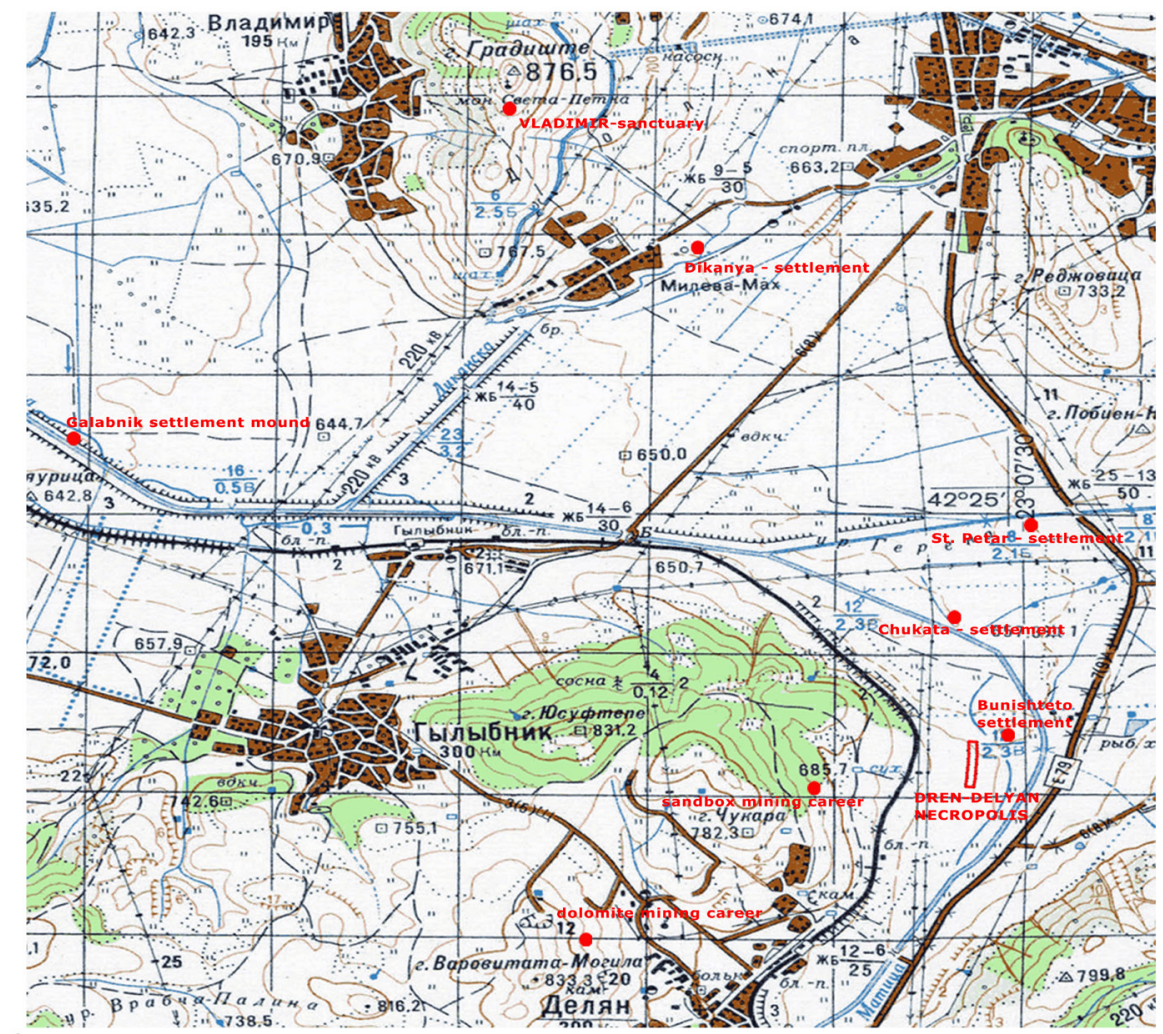

2

Fig. 5. 1. Quarries for stone extraction in the proximity of the necropolis;

2. Map of nearby settlements

Сл. 5. 1. Рудници камена у близини некрополе; 2. Мапа оближњих насеља 
had been collected in urns; in others, the remains had been brought and dumped directly upon the stones (Fig. 4: 3). The inventory consists chiefly of items of personal adornment and weapons. During the second phase of the necropolis, in addition to cremations, rare examples of inhumation also occur (Mihaylov, Galabova, in press).

\section{Grave goods and gifts}

The pottery assemblage from the site is of poor quality. During the first phase of the necropolis, most common are the conical shallow bowls and the bowls with inverted lip. The latter are often decorated with oblique flutes on the lip, a panel with incised linear motive under the rim, or - rarely - four symmetrically distributed knobs, rising above the lip (Fig. 3: 5). Both types of bowls had been utilized primarily as lids for the urns, which, on their part, are almost universally bi-conical, with cylindrical necks and out-turned lips (Fig. 3: 5, 7). In terms of grave goods, shallow bowls, cups and pitchers were found. The handles on most pitchers are raised above the rim (Fig. 3: 8). The decorative repertoire consists primarily of incised linear motives, shallow flutes, and small knob-horns. Although less common, incised, stamped, and printed motives have also been registered. The ornamental scheme is simplified and discreet. A distinctive feature is four (or two) decorative handles or knobs, attached symmetrically (Fig. 3: 7, 8).

Some of the grave goods - chiefly the very wide shallow bowls with inverted rims, are almost unbaked - rather briefly exposed to heat, and they disintegrate when unearthed. These were likely produced specifically for the funerary rituals.

\section{Similar objects and finds}

Geographically speaking, the closest excavated synchronous site is the Galabnik settlement mound (Fig. 5: 2), where numerous pits containing materials dated into the first phase of the EIA have been registered (Чохаджиев 1983, 5-6; Георгиева 2003, 167-168, T. III, 3-8; 10-17). The best parallels for the pottery assemblage from the first phase of the necropolis (as well as for that from the Galabnik Tell) are found in the Južna Morava region (Stojić 1986, T. X, 4, 6-12, VIII, 1-3; Стојић 2004, 52-53, T. XXX; 109, T. LXXXIX; 116-117, T. XCVI; T. V-VII, T. XXI; T. 1; T. 9-11; Булатовић 2005, 78-79, T. III/19), Nišava (Jevtić 1983, T. X, 5; T. XIX, 5, 59; T. XLI, 7) and Pčinja - all the way up to Upper Vardar River (Stojić 2003: 126, T. IV, 6; 9-12; 129, T. VII1 1-4 и 7-8). Similarities were also identified in pottery assemblages from Upper Mesta River, the Western Rhodope Mountains and the Northern Aegean. 
A few fragments of fibula bows are associated with the first phase of the necropolis. Most of them were discovered without a context. One, however, was found in an urn from Structure 37 (Fig. 3: 6). A fragment of the identical fibula was likely removed by a plough from some of the urns of the so-called Structure 37. It belongs to a Type B I1 fibula (Gergova 1987, 36-38, T. 8), with a date range between the $11^{\text {th }}$ and the $8^{\text {th }}$ century BC. This is likely the broadest frame for the dating of the first phase on the necropolis.

From the second phase, the following metal finds are particularly important: a silver circlet, silver and gold earrings (Fig. 4: 4-5), a pair of linked bronze circlets (Fig. 4: 6), gilded bronze tweezers, numerous silver, bronze, amber and glass beads (Fig. 4: 7), bronze spiral "armlet", iron knives, spearheads, circlets, fragments of horse trappings, etc. Although rare, status insignia were also found as grave goods - silver lunulae (Fig. 4: 8), gold pectorals and decorative foil sheets (Fig. 4: 9).

The large number of finds coupled with the proximity to a number of gold and silver deposits, the use of a variety of techniques and of combinations of metals implies a local goldsmith workshop.

Gold pectorals or plaques were found in six of the excavated structures. All had been deposited according to specific burial rites. The artefacts enrich our knowledge of Thracian jewellery traditions. On the basis of the specifics of production and the decoration, it can be assumed that the pectorals and plaques found at the Dren-Delyan necropolis had been produced by a goldsmith workshop in the $5^{\text {th }}$ century BC, in the Thracian art style (Михайлов, Пировска, in press). Gold particles in several glass beads, identified through an AMS analysis, are also of great interest (Mihaylov, Tzankova, in press). The data from the analysis is presented in the tables below ${ }^{3}$.

Several fragments of bronze and iron fibulae were also found within the stone structures. Unfortunately, all finds were those of bows, making it difficult to assign them to a type and or a narrow date. The most numerous finds (accounting for more than half of the finds) are fibulae of the so-called "Thessalian type" (Бакъмска/ Михайлов 2012, 190, Обр. 3:2), widespread during the $7^{\text {th }}-6^{\text {th }}$ century $\mathrm{BC}$ over the entire territory of Western Bulgaria.

\footnotetext{
${ }^{3}$ Determination of gold content was performed with a JEOL JSM-6610LV X-ray microanalyzer (microbeam), equipped with SE, BSE, WDS, and CL detectors, at the Faculty of Mining and Geology at the University of Belgrade. The determination of contents of other components was performed in the laboratory of LA-ICP-MS, using an excimer laser from the NWR UP193FX system coupled to a Perkin-Elmer ELAN DRC-e ICP MS (Institute of Geology, BAS).
} 


\begin{tabular}{|l|l|l|l|l|l|l|}
\hline $\begin{array}{l}\text { Structure } \\
\text { Објекат }\end{array}$ & 39 & 19 & 39 & 16 & 33 & 33 \\
\hline Au \% & 70.20 & 89.89 & 70.26 & 89.24 & 78.63 & 73.48 \\
\hline Ag \% & 29.23 & 10.07 & 29.18 & 10.73 & 21.11 & 26.12 \\
\hline Cu \% & 0.54 & 0.02 & 0.52 & 0.02 & 0.24 & 0.37 \\
\hline Fe \% & 0.11 & 0.14 & 0.14 & 0.22 & 0.26 & 0.34 \\
\hline Mn ppm & 10.98 & 7.93 & $<5.236$ & 12.19 & 9.31 & 7.62 \\
\hline Pd ppm & 90.16 & 34.89 & 83.36 & 24.80 & 51.27 & 59.73 \\
\hline Sb ppm & 7.03 & 15.87 & 5.99 & 13.91 & 5.61 & 8.09 \\
\hline Sm ppm & 27.60 & 10.19 & 23.90 & 8.64 & 17.17 & 21.71 \\
\hline Pb ppm & 128.82 & 116.06 & 162.64 & 82.49 & 111.01 & 162.39 \\
\hline Bi ppm & 70.44 & 3.99 & 78.45 & 1.85 & 9.62 & 18.60 \\
\hline
\end{tabular}

Table 1. LA-ICP-MS analysis of gold pectorals or plaques from the Dren-Delyan necropolis

Табела 1. LA-ICP-MS анализа златних пекторала или плочица са некрополе Дрен-Дељан

\begin{tabular}{|l|c|c|}
\hline $\begin{array}{l}\text { Sample } \\
\text { Узорак }\end{array}$ & 001 & 002 \\
\hline Au \% & 58.25 & 61.04 \\
\hline Ag\% & 21.23 & 18.66 \\
\hline
\end{tabular}

Table 2. Chemical composition of golden particles found in beige and orange glass beads from the Dren-Delyan necropolis (Mihaylov, Tzankova, in press)

Табела 2. Хемијски састав честица злата нађених у беж и наранџастим стакленим перлама са некрополе Дрен-Дељан (Mihaylov, Tzankova, in press)

\section{Nearby settlements and similar necropoles}

The closest synchronous settlement is found $100 \mathrm{~m}$ to the north-east (Fig. 5: 2). Considering the fact that its surface area is just 2 decares, it is difficult to accept it was the only one using a necropolis as a large as this one. At the site of Chukata in Dren (Fig. 5: 2), some 800 m north of the necropolis, previous excavations had registered another synchronous settlement (Бакъмска, Михайлов 2013, 538), and $1.5 \mathrm{~km}$ to the north-east, at the site of St. Peter in Dren - a third such settlement site (Fig. 5: 2). The residents of those settlements likely shared the use of the necropolis. Yet even these three settlements could hardly have been the only ones, given its size, the riches and the number of power insignia artefacts found. 
On top of the Galabnik settlement mound, $5.5 \mathrm{~km}$ to the west (Fig. 5: 2), there are remains of a settlement from the first phase of the Early Iron Age, from which only the sunken features had been preserved. The pottery assemblage associated with those features provides the best parallels for the first chronological phase of the necropolis.

According to the locals, $5.7 \mathrm{~km}$ north-west of the necropolis, on the southern terrace below the summit of the detached elevation "Gradishte" (by the village of Vladimir) overseeing the entire Radomir Plain (Fig. 5: 2), $7^{\text {th }}-6^{\text {th }}$ century BC ritual bronze artefacts (the so-called "bird cages") had been found. At the southern foot of this elevation, a large and rich settlement from the first millennium BC had been registered - which, unfortunately, has not been surveyed archaeologically.

During the excavations on tell Galabnik, a burial structure, the closest in terms of geography, was discovered. The skeletons of two individuals had been deposited in a pit. Based on the pottery finds, the grave is dated within the first phase of the Early Iron Age (Бакъмска 2014, Обр. 5).

At Staro Selo, Radomir District, another geographically and chronologically close necropolis had been registered. Several large tumuli may represent a clan necropolis. The excavated tumuli had been dated into the period between the $5^{\text {th }}$ and the $1^{\text {st }}$ century BC. They are low, with stone or stone-and-earth embankments. Each contained more than one burial. The prevalent ritual is cremation, with bones placed in urns or dumped in graves. The practice of inhumation is attested in the earliest graves. Structures associated with the commemorative rituals had also been excavated (Паунова 2006, 150).

Although there is no exact parallel in terms of the length of use, judging by some graves finds, the plan, the dimensions, the evolution of the burial structures and the conservative burial practice, the Dren-Delyan necropolis is not an isolated phenomenon. Separately, Dren-Delyan distinctive features are attested on many sites. Closest, in terms of geography, chronology and type, are the necropoles by Sinjac-Selište, in the valley of the Nišava River, Serbia (Kapuran, Blagojević, Bizjak 2015, 149, fig. 3, 150, fig. 4); Bajlovo, Sofia District, Bulgaria (Попов 1924, 68-85); the large necropolis between Kochan and Satovcha, Blagoevgrad District, Bulgaria (Gergova 1989, 231-240; Gergova 1995, 34-48); Radanja, Karbinci Municipality, North Macedonia (Гарашанин 1959, 9-60); Star Karaorman, Štip Municipality, North Macedonia (Микулчиќ 1959; Микулчиќ 1960-61, 47-62); Atenica, Čačak Municipality, Serbia; Krševica, Bujanovac Municipality, Serbia; the Glasinac necropolis; several graves and necropoles in Eastern Slovenia (Dular 2003); South-western Romania, etc. 
Neither of the sites listed above, however, displays either the durable planning nor the idea for the development of the necropolis - the building of a large number of burial structures, of structures associated with the funerary and commemorative rituals and empty spaces, for easy access to the structures.

\section{Conclusion}

The necropolis is unique by both its scale and its structure - huge stone burial structures, set up in an area lacking in stone sources, following a predefined design for the extended use of the land and the structures.

The people who constructed graves and memorial sites in the $6^{\text {th }}-4^{\text {th }}$ century BC possessed knowledge about the $11^{\text {th }}-9^{\text {th }}$ century BC burial structures. Proof of this is that the $6^{\text {th }}-4^{\text {th }}$ century stone structures had been constructed, often arranged even, around the earlier graves, without destroying or disturbing them (see also Михайлов 2014; Mihaylov, Galabova, in press). Such behaviour is dependent upon a preserved lineage cultural memory. Furthermore, the prototype for the structures used in the $6^{\text {th }}-4^{\text {th }}$ century BC originated in the final years of the first phase of the necropolis: in Structure 41 (Fig. 3: 4). The entire logic of the necropolis, and the burial and commemorative gifts recovered from it lead us to believe that it had remained in use during the $8^{\text {th }}-7^{\text {th }}$ century BC. The absence of archaeological assemblages and structures from this period is likely the consequence of chance: the size and shape of the excavated area were determined by the rescue nature of the archaeological survey, not by academic agenda. The culture is the same; the $6^{\text {th }}-4^{\text {th }}$ century population knew of and observed the $11^{\text {th }}-9^{\text {th }}$ century BC graves; the small finds and burial structures demonstrate a logical progression and transformation. All of the above substantiates the hypothesis that for 600 years, the same group of people had used the necropolis to bury their relatives. Such continuity in making strategies and funerary practices requires a doctrine, a political institution, and substantial economic resources.

The issue of the identity of the users of this necropolis remains to be resolved. This overview demonstrates that none of the known synchronous settlement sites in the immediate proximity matched either the size or the wealth of the necropolis. Moreover, the prevalent practice at the necropolis is cremation - a custom facilitating transportation of the remains across longer distances. The results of the geophysical surveys conducted in 2015-2018 preclude the presence of a funerary pyre (Fig. 2: 1) within a $400 \mathrm{~m}$ radius from the necropolis. The high intensity magnetic signature of the structures comprising the site of the necropolis make it impossible for the magnetometer to miss it. 
Indisputably, the graves with gold goods had been intended only for people of high social status. Therefore, in a region with no notable settlement structure, such large "aristocratic" necropolis could only be interpreted as regional.

\section{REFERENCES}

Бакъмска, А., 2014. История на археологическите проучвания на селищната могила Гълъбник (1979-1993), Известия на Регионалния исторически музей-Перник 2: 43-59.

Бакъмска, А., Михайлов, Ф. 2012. Спасително археологическо проучване на некропол от желязната епоха по трасето на ЛОТ 1 от АМ „Струма”, км 311+000 до 311+500, село Делян, община Дупница, у М. Гюрова (ред.) Археологически открития и разкопки през 2011 г., 188-190. София: Българска академия на науките, Национален археологически институт с музей.

Бакъмска, А., Михайлов, Ф., 2013. Археологическо наблюдение на изкопните работи по трасето на АМ „Струма“ км 307+100 до км 310+620, М. Гюрова (ред.) $A p$ хеологически открития и разкопки през 2012. 538. София: Българска академия на науките, Национален археологически институт с музей.

Булатовић, А. 2005. Керамика брњичке културне групе и старијег гвозденог доба са налазишта Кале у Кршевици. Зборник Народног музеја XVIII-1: 175-190.

Corriera, P. 1997. Fire modification of bone: a review of the literature, in: W. D. Haglund, M. H, Sorg (eds.), Forensic taphonomy: the post-mortem fate of human remains, 275-293. CRC Press, Boca Raton Florida.

Чохаджиев, М. 1983. Разкопки на праисторическото селище край с. Гълъбник, Пернишки окръг, у Археологически открития и разкопки през 1982, 5-6. Плевен.

Dular, J. 2003. Halštatske nekropole Dolenjske (Opera Instituti Archaeologici Sloveniae 6), Ljubljana: Inštitu za arheologijo ZRC SAZU.

Гарашанин М. и Гарашанин, Д. 1959. Археолошка ископавања у селу Радану, на локалитету „Криви дол”, Зборник на Штипскиот Народен музеј 1: 9-60.

Георгиева, Р. 2003. Керамиката от ранната желязна епоха в Югозападна България и феноменът „Цепина“, Пирајхме 2: 159-196.

Gergova, D. 1989. Thracian burial rites of Late Bronze and Early Iron Age, in J. G. P Best \& N. M. W. de Vries (eds.) Thracians and Mycenaeans: proceeding of the Fourth International Congress of Thracology, Rotterdam, 24-26 September 1984, 231-240. Leiden: W. J Brill; Sofia: Terra Antiqua Balcanica.

Gergova, D. 1995. Culture in the Late Bronze and Early Age in South-West Thrace (Upper Mesta and Middle Struma Valleys, Зборник, археологина н.с. I. Скопје: 34-48.

Gergova, D. 1987. Früh- und ältereisenzeitliche Fibeln in Bulgarien, Prähistorische Bronzefunde Abt. XIV, 7. München: C. H. Beck.

Jevtić, M., 1983. Keramika starijeg gvozdenog doba na centralnobalkanskom području, Beograd: Univerzitet u Beogradu, Filozofski fakultet, Centar za arheološka istrazivanja. 
Kapuran, A., Blagojević, M., Bizjak, D. 2015. Settlements and necropolises of the Early Iron Age along the middle course of the Nišava River, Старинар LXV: 145-181. Михайлов, Ф. 2014. Резултати от спасителните археологически разкопки на некропол от I хил.пр.Хр. край село Делян, Известия на Регионалния исторически музей - Перник 2: 60-76.

Михайлов, Ф. 2016. Археологическо проучване на некропол от I хил. Пр. Хр. между селата Дрен, общ. Радомир и Делян, общ. Дупница, у А. Аладжов (ред.) Археологически открития и разкопки през 2015. г, 284-286. София: Българска академия на науките, Национален археологически институт с музей.

Михайлов, Ф., 2019. Археологическо проучване през 2018 г. на некропол от I хил. пр. Хр. между селата Дрен, Радомирско и Делян, Дупнишко, у Х. Попов (ред.) Археологически открития и разкопки през2018. г., 378-379. София: Българска академия на науките, Национален археологически институт с музей.

Михайлов, Ф., Цанков, Хр. 2016. Геофизично проучване на некропол от I хил. пр. Хр. между селата Дрен, Радомирско и Делян, Дупнишко през 2015 година, у А. Аладжов (ред.) Археологически открития и разкопки през 2015. г., 924-927. София: Българска академия на науките, Национален археологически институт с музей.

Михайлов, Ф., Цанков, Хр., 2018. Геофизично проучване на некропол Дрен-Делян през 2017 година, у А. Аладжов (ред.) Археологически открития и разкопки през 2017. 2., 691-693. София: Българска академия на науките, Национален археологически институт с музей.

Mihaylov, Ph., Tzankova, N. in press. Glass beads from Dren-Delyan necropolis (archaeological and chemical study), in 13th International Congress of Thracology "Ancient Thrace: Myth and Reality".

Mihaylov, Ph., Galabova, B. in press. The necropolis Dren-Delyan (11th-4th century BC.). Cultural and physicalanthropological analyses, in 13th International Congress of Thracology “Ancient Thrace: Myth and Reality”, Kazanlak, 2-7 September 2017.

Михайлов, Ф., Гюрова, М. 2015. Археологическо проучване на некропол от I хил. пр. Хр. между селата Дрен, Радомирско и Делян, Дупнишко, у Г. Кабакчиева (ред.) Археологически открития и разкопки през 2014. г., 153-157. София: Българска академия на науките, Национален археологически институт с музей.

Михайлов, Ф., Пировска, А. in press. Златни нагръдници и пластини от некропола между селата Дрен и Делян. у Сборник в чест на Иван Венедиков.

Микулчиќ, И. 1959. Извештај са пробног ископавања халшатске некрополе код села Стар Караорман, Зборник на Штипскиот Народен музеј 1: ???

Микулчиќ, И. 1960-61. Могили од „Орлова чука” кај село Караорман, Зборник на Штипскиот народен музеј 2: 47-62.

Николов, В., Йорданова, М. 2002. Планините в България. София: Издателство на БАН „Проф. Марин Дринов”.

Паунова, В. 2006. Проучване на могилен некропол в с. Старо село, Радомирско, м. Равнището, у Х. Попов (ред.) Археологически открития и разкопки през 2005. г., 150-160. София: Българска академия на науките, Национален археологически институт с музей. 
Попов, Р. 1924. Некрополът при с. Байлово, Софийско, ИБАИ 1921-1922: 68-85. Stojić, M. 2003. Baseni Južne Morave i Pčinje u vreme razvoja brnjičke kulturne grupe, Пирајхме 2: 119-142.

Stojić, M. 1986. Gvozdeno doba u basenu Velike Morave. Beograd: Univerzitet u Beogradu, Filozofski fakultet.

Стојић, М. 2004. Пањевачки рит, Београд: Археолошки институт.

Зидаров, П., Бакъмска, А. 2012. Недеструктивни проучвания на археологически Обект № 2, ЛОТ 1 по АМ „Струма”, край село Делян, община Дупница, у М. Гюрова (ред.) Археологически открития и разкопки през 2011. г., 186-188. София: Българска академия на науките, Национален археологически институт с музей. 


\section{Филип Михајлов}

Регионални историјски музеј - Перник, Бугарска

\section{ЗАШТИТНО ИСКОПАВАЊЕ НЕКРОПОЛЕ ДРЕН-ДЕЉАН, ЈУГОЗАПАДНА БУГАРСКА}

Кључне речи: некропола, рано гвоздено доба, касно гвоздено доба, златни пекторали, стаклене перле, урна, долина Струме, југозападна Бугарска

Током заштитних ископавања код места Буништето и Другански Пут, откривена је дотад непозната некропола и делимично је истражена. Пронађене су гомиле камења у дужини од око 400 м на површини од 6575 $\mathrm{M}^{2}$. У неким гробовима су нађени кремирани посмртни остаци, стављени у урне са прилозима, док су други били покривени каменовима или постављени између каменова.

Најстарији гробови се налазе у јужном делу некрополе и представљају урне са кремираним костима, које су одлагане у плитке јаме и покриване плочама. У неким случајевима су биле означене великим, безобличним каменовима. Током истраживања, око 55 гробова је регистровано, датирано у прву фазу старијег гвозденог доба, као и отприлике исти број гробова из 6-4. века п. н. е. Већина гробова из старијег гвозденог доба није имала дарове изван урни. Гробови из млађег гвозденог доба су имали релативно богате гробне прилоге с обзиром на област у којој се налазе. Некропола је постојала током два археолошка периода - старијег и млађег гвозденог доба. Јединствена је по својој величини, као и структури - у области без иједне камене формације постављане су огромне камене конструкције са унапред одређеним планом за континуирано коришћење терена и грађевина. Вероватно је то била обласна некропола, где су сахрањивани представници локалне аристократије. Друго објашњење би могла бити близина богатих налазишта руде на Коњавској планини те планинама Витоша и Верила. 